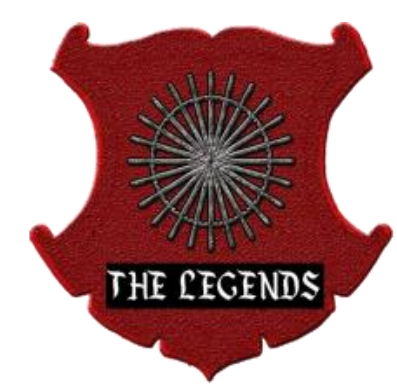

Submitted / Geliș Tarihi: 06/07/2021

\section{THE LEGENDS JOURNAL OF EUROPEAN HISTORY STUDIES( LJEHS)}

Issue / Sayı: 2 Year / Yıl: 2021

Article Type / Makale Türü: Çeviri Makalesi / Translation Article Doi: http://dx.doi.org/10.29228/legends.52015

Reference / Atıf Bilgisi: Şeyban, Lütfi; "Endülüs'ün İspanyol Tarihî Belleğinde Çarpıtılması”, The Legends Journal of European History Studies, S. 2, 2021, ss.130-140.

\title{
ENDÜLÜS'ÜN İSPANYOL TARİHÎ BELLEĞİNDE ÇARPITILMASI *
}

\author{
Alejandro García Sanjuán*
}

Çevirmen: Lütfi ŞEYBAN *

\section{DISCRIMINATION OF ANDALUSIA IN THE MEMORY OF SPANISH HISTORY}

Tarihî hâfıza kavramı, belirli bir toplumda geçmiş hakkında bütünlüklü fikirler manzumesi olarak anlaşılabilir. Bu fikirler asla tekdüze olmayıp, aksine birbirinden radikal biçimde farklılaşan karşıt bakış açıları ortaya koyabilecek niteliklere de sahiptirler. İspanya'da bu konuda belki de en etkili örnek, 2007'de sözde "tarihî hâfıza yasası"nın ilan edilmesini sağlayan İç Savaş olmalıdır.

Her ne kadar bu yasa sadece iç savaşın ve ardından gelen Francisco Franco diktatörlüğünün sonuçlarına atıfta bulunsa da, gerçekte "tarihî hâfıza" kavramı çok daha geniş bir anlama sahiptir ve aynı zamanda Ortaçağ asırlarını da kapsamaktadır. İspanya'da, İber Yarımadası'nda bir Arap ve İslam ülkesi olan Endülüs'ün 711-1492 yılları arasındaki tarihi varlığı, kolektif tarihî hâfıza açısından en sorunlu unsurlardan birini teşkil etmektedir.

XIX. yüzyıldan itibaren İspanya'ya dair bir milli tarih inşasının gelişim süreci, Endülüs dönemini anlamada uzun bir seyre ve aynı zamanda geniş bir projeksiyona sahip olup, içerisinde biri akademik camiada ve diğeri akademi dışında olmak üzere iki karşıt yaklaşımı barındırır. Bu iki yaklaşım tarzı, bünyesinde hem Endülüs'ü mitleştirenlerin sevimli ve

\footnotetext{
* Makalenin yayın künyesi: Alejandro García Sanjuán, "La distorsión de al-Andalus en la memoria histórica española”, Intus-Legere Historia, ISSN 0718-5456 / Año 2013, Vol. 7, No. 2; pp. 61-76, DOI: 10.15691/07176864.2014.100. Gerekli izinler alınarak çevrilmiştir.

* Prof. Dr., Sakarya Üniversitesi, seyban@ @akarya.edu.tr Orcid no: 0000-0002-1825-0097
} 
olumlayıcı fikirlerin hem de Endülüslü ile İspanyolun tam uyumsuzluğuna dayanan muhalif fikirlerin bir arada bulunduğu ortak bir tahayyül oluşturdu.

Geçmişin günümüz üzerindeki belirleyici etkisi, birbirine zıt bu iki hafizanın içerisindeki mitler, önyargılar, ezberler, aklı esas almayan yaklaşımlar ile tarihî yanılgılar (anakronizm) yoluyla sürdürülmektedir. Bu etkinin nesiller boyu yayılmasıysa, eğitim sistemleri, iletişim, edebiyat, sinema, medya vb. yollarla gerçekleşmiştir. Hem de Endülüs'ün mitleştirilmesi ile inkârı arasındaki diyalektiğin akademik tarihyazım pratiğinden kaynaklandığının bilinmesine rağmen.

Her türlü tarihi tahrifat ve mitler üzerine eleştirel düşünme, topluma geçmişin bilimsel analizine dayanan ve hâfızadaki önyargılardan uzak kavramsal araçlar sunmakla yükümlü bulunan profesyonel tarihçinin en önemli görevlerinden birisidir. Endülüs konusu özelinde böyle bir çalışma aciliyet arzetmektedir. Çünkü söz konusu unsurların olağanüstü zinde oluşu, bunların devamlılığını sağlayan sebepler üzerinde düşünmeyi zorunlu kılmaktadır.

\section{Evvelkiler ve Gelişim}

\section{İki İspanyol Paradigmasının Endülüs Üzerine İşlenmesi}

XIX. yüzyılda tarihyazımının belirlemiş olduğu düşünce, o döneme özgü politik değişimler ve çeşitli alanlarda deneyimlenen epistemolojik dönüşümler vasıtasıyla kalıcı gelişmeler gösterdi. Bu süreçteki en belirleyici unsurlardan biri, geleneksel aktörleri, monarşiyi ve kiliseyi tamamen yerinden etmese de halkı ve milleti tarihi evrimin yeni kolektif kahramanları olarak konumlandıran milliyetçilikti.

XIX. yüzyıl İspanyol tarihyazımı, Endülüs dönemine bakışta iki farklı karakterizasyonunu öyle etkili formüle etti ki bu iki karakterden her ikisi de önyargılarla ağırlaştırılarak neredeyse hiç değişmeden günümüze kadar devam etti. Bu tarihi sahnenin yorumlanmasındaki ana çarpıtma faktörü ise İspanya'daki Bask, Katalan, Gāliçyalı, Endülüslü veya Kanarya Adalı gibi diğer milliyetçiliklerden çok daha büyük bir kapsama sahip olan İspanyolculuk olmuştur. Bu akım, kapsama gücünü, geçmişe dair söylemi geniş ölçüde yanlış ifade ederek ve etki kapasitesi çok daha sınırlı olan ilgili davalardan alıntılar yapmak suretiyle elde etmiştir.

İspanyolculuğun en muhafazakâr biçimi, Katolik ve İspanyol arasındaki kalıcı kimliğin onaylanmasından oluşmuş ve bu da Katolik-milliyetçiliği ideolojisini doğurmuştur. Muhtemelen hiç kimse bu ideolojiyi, Historia de los heterodoxos españoles - 1880-82 (Heterodoks İspanyolların Tarihi) adlı eserinde, antolojik bir formülasyonla İspanya fikrini Katolikliğin özü olarak özetleyen ünlü Santander'li yalan makinesi Marcelino Menéndez Pelayo'dan daha iyi ifade etmemiştir: "İspanya, dünyanın yarısının müjdecisi (Hıristiyanlık misyoneri). İspanya, kâfirlerin çekici, Trento'nun 1şı̆̆ı, Roma'nın kı1ıc1, Aziz Ignatius'un beşiği (...). Bu bizim büyüklüğümüz ve birliğimiz, başka bir şeye sahip değiliz". ${ }^{1}$

Endülüs'ün en tutucu İspanyolculuk tarafından nitelendirilmesinde olumlu bir anlam aramak, Endülüs'ün İslami boyutu ile İspanyol ulusal kimliğinin güçlü Katolik çağrışımları arasındaki zıtlık göz önüne alındığında imkânsızdır. İspanya'nın "doğal" tarihi evrimi bakımından

\footnotetext{
${ }^{1}$ Marco, L., El Catolicismo identitario en la construcción de la idea de nación española (İspanyol ulusu fikrinin inşasında Kimlikçi Katoliklik); Menéndez Pelayo, Historia de los Heterodoxos Españoles içinde: Ilu, 14, s. 111.
} 
haksızlık fikri ve bu haksızlığın ortadan kaldırılması ihtiyacının ifade edilmesinde kullanılan "İspanya'da Arap işgali" mefhumu aracılığıyla Endülüs, temelinden sorgulanmıştır. Bu sorgulama, kutsanan Batı medeniyeti ve bu medeniyetin Katolikliği çerçevesinde aşağılayıcı bir perspektiften yapılmıştır. ${ }^{2}$

Mantıki kavramları tersine çevirme yaklaşımı olarak "istila" fikri, "Reconquista"nın (Hristiyan yeniden fethi) İspanyolların 711'de Müslümanlar tarafından "işgal edilen" bölgeyi geri almak için ulusal kurtuluş mücadelesi olarak anlaşıldığ 1 dönemde benimsenmişti. $\mathrm{O}$ zamandan beri bu fikir, Franco diktatörlüğü sırasında zirveye ulaşan İspanyolculuk söyleminin ana unsurlarından birisini teşkil etti. İspanya'nın birleşmesi fikrinin benimsenmesi, Endülüs'ün ortadan kaldırılması gereğini ima ettiğinden dolayı, İspanyolculuğun ideolojik çerçevesi içinde Endülüslünün dışlanmasına işaret ediyordu. $\mathrm{O}$ vakitten itibaren İspanyolculuk düşüncesini karakterize eden güçlü İslam karşıtı çağrışımların nedeni budur.

XIX. yüzy1ldan bu yana ise İspanyolculuk, istila - Reconquista ikili teriminden doğan olumsuz Endülüs fikrine karşı yükselen tepkiler karşısında Endülüslülerin İspanyollaştırılmasını ifade eden aykırı yaklaşımın ikinci paradigmasını oluşturdu. Buna göre "Müslüman İspanya" fikri, özünde otokton doğanın yani ülkenin yerlisi olma hakikatinin onaylanmasından ibarettir. Ancak, bu yaklaşımda da "İspanyol", Endülüslülerin ana değerleri ile ülkeye olan kültürel, sanatsal ve edebi katkılarını yabancı sayar ve onu Arap ve İslami boyuta indirgeyerek dişlar.

Endülüs'ün İspanyol söylemindeki karakterizasyonuna ilişkin bu iki karşıı paradigmanın XIX. yüzyıldan bu yana birlikte var olması, tüm milliyetçi tarihyazım söyleminin doğasında bulunan çelişkileri ve sınırlamaları vurgulamaktadır. Buna rağmen, akademik dünyada üretilen her iki vizyon da, İspanyol nesillerini efsaneler, ezberler, önyargilar ve anakronizmlerle besleyerek, derin şekilde deforme olmuş bir tarihî hâfızayı yapılandırdı. Sonraki aşamalarda ise bunlara yeni içerikler eklendi.

\section{Francoculuk ve Ulusalkatolik İspanyolculuğun Altın Çağları}

İç savaş sırasındaki başlangıcından itibaren Francoculuk, ana ideolojik desteğini Ulusalkatolikçi akımın içerisinde buldu. İspanyol Katolik Kilisesi hiyerarşisi, darbesini Marksizm'e ve ateizme karşı bir haçlı seferi olarak tanımlayan Franco'ya tam destek verdi. Bu sayede, Katolik ve imparatorluk geçmişinin yüceltilmesiyle belirlenen Reconquista kavramıyla ilişkili tarihî bellekte güçlü bir yükseliş olacaktı.

Manuel Machado'nun 1937'de yazdığı ünlü şiirinde diktatörün kendisi, kelimenin tam anlamıyla "Yeni Reconquista'nın Caudillo'su" ("kazanmayı ve gülümsemeyi bilen" ve şiirini bir üçlü ile bitiren adam) olarak nitelendirildi. Aynı şekilde yeni Francocu devletin, Katolik monarşilerden San Juan kartal1, boyunduruk ve oklar gibi (Faşist ideolojiye sahip İspanyol siyasi partisi Falange'nin bayrak kalkanında da kullanılan) unsurları resmî sembol olarak benimsemesi, onun Reconquista kavramıyla tam olarak özdeşleşme çabasını ortaya koymaktadır. Nitekim Isabel ve Fernando monarşisi, Granada'nın zaptını yalnızca

\footnotetext{
${ }^{2}$ García Sanjuán, A., La Conquista Islámica de la Peninsula Ibérica y la tergirversación del pasado: del catastrofismo al negativismo, Madrid, 2013 (İber Yarımadası'nın İslami Fethi ve geçmişin tahrif edilmesi: felaketten kötümserliğe, Madrid, 2013).
} 
Reconquista'nın zirvesi değil aynı zamanda hem imparatorluk İspanya'sının hem de Amerika "evanjelizasyonunun" başlangıç noktası sayıyordu.

Ulusalkatolikçilik dönemiyle Reconquista kavramının doruk noktasına denk gelen dönemin çakışması hiç de tesadüf değildir. Her iki süreç arasındaki eşzamanlılık, Reconquista'nın bu ideolojinin ihtiyaçlarına mükemmel şekilde uyarlanmış bir tarihyazımı kavramı oluşturduğunu göstermektedir. Başka bir deyişle Reconquista, bu radikal İspanyolcu bakış açısının tarihî belleğini diğer tüm kavramlardan daha iyi ifade etmektedir.

Franco'nun propagandası kapsamında, mücadelesi Haçlı seferi ve Reconquista kahramanlarıyla özdeşleştirilen Caudillo yeniden yaratılırken; zamanın akademik tarihyazımı da muazzam çelişkilerle dolu bir içerikle İspanyol belleğine özgü kötü şöhretli tarihî önyargıları besledi. Paradoksal olarak o devrin bu mazi vizyonunun ana temsilcisi, Arjantin'e sürgün edilmiş bir cumhuriyetçi olan ve bu nedenle Franco diktatörlüğüyle her türlü kişisel veya kurumsal ilişkisi tamamen kesik bulunan Ortaçağcı Claudio Sánchez-Albornoz idi. Bununla birlikte, onun çalışmaları Ulusalkatolik tarih yazımının ve onunla bağlantılı mit ve önyargıların doruk noktasını temsil etmektedir.

Bazı temel çalışmalarında Sánchez-Albornoz, Endülüslülerin kültürel tezahürlerinin derin İspanyolluğunu iddia etti. Örneğin ünlü Kurtubalı yazar İbn Hazm'1, 'Unamuno'dan Seneca'ya birleşen zincirdeki Mağribî halkası" olarak takdim etti. ${ }^{3}$ Bununla birlikte Avilalı Ortaçağcı, "Müslüman İspanya" fikrine bağlı kalarak, İspanyolların ulusal kimliğinin şekillendirilmesinde ve İspanya'nın tarihinin yapılandırılmasında temel bir dönem olarak Reconquista kavramının en büyük mucidi oldu. Hayatının sonunda Reconquista fikrini tercih ettiğini De la Andalucía islámica a la de hoy - 1983 (İslami Endülüs'ten Bugüne) adlı eserinde göstererek, (ideoloji ile bilim arasında düştüğü, L.Ş.) çelişkiyi gidermeye çalıştı.

İç savaş ve Franco rejimi, aynı zamanda İspanyolculuğun ürettiği başka bir tarihyazımı mitinin de gebelik muhitiydi. İç savaştan önceki yıllarda, faşizmin aşırı milliyetçi sempatizanı Ignacio Olagüe tarafından formüle edilen ve Müslümanların- Iber Yarımadası'nı fethini inkâr edici yaklaşımdan bahsediyorum. Bask sözde tarihçisinin La revolución islámica en Occidente - 1974 (Batıda İslam Devrimi) adlı eserinde șekillendirdiği fikirleri, tarihyazımı sahtekârlığının çok etkili örneklerinden birisidir. Birleştirici İspanyolculuğun ihtiyacına yanıt veren öncüllerden biri olarak Olagüe, Endülüs'ün tarihi kökenini, "yerli güçlerin ve eğilimlerin evrimi sonucu Endülüs'ün oluşumu” fikrine dayalı olan süreklilik söylemiyle özetliyor.

Franco'nun ölümüyle demokrasiye geçiş sürecinde, özellikle Galiçyalı, Katalan, Bask, Kanarya Adalı ve Endülüslü olmak üzere çevresel milliyetçilikler doğdu. Endülüs milliyetçiliği, İspanya'daki tek milliyetçi ideoloji olmanın özgünlügünü sunar ve bu görüş Endülüs'ü, ulusal kimliğin tarihi yapısı içerisinde merkezi bir unsur olarak konumlandırır. Bu eğilimin en keskin tezahürleri, Endülüs'ün geri alınmasını ve Granada'nın kapitülasyonlarına uyulmasını talep eden bir parti olan Liberación Andaluza'nın İslami Endülüs sektörleriyle bağlantılarıdır. Partinin aldığı en iyi seçim sonucu, 1987 belediye seçimlerinde Algeciras Kent Konseyi'nde (Cádiz) üçüncü siyasi güç haline gelmesiydi. Bu veriler, bir yandan bu gruplar tarafindan desteklenen söylemin zayıf sosyal izdüşümü hakkında bir fikir edinmemizi sağlarken, diğer yandan da Franco rejimi tarafından kırk yıla yakın sürdürülen ve daha sonra muhafazakâr medya ve siyasi sektörlerin ideolojisiyle bütünleşmiş İspanyolculuğun sürdürdüğ̈ fikirlere taban tabana zittır.

\footnotetext{
${ }^{3}$ C. Sánchez-Albornoz, El Islam de España y el Occidente, Madrid, 1974, s. 111-113.
} 
İspanya'da özerk devlet yapısının gelişimi çerçevesinde İspanyolculuk dışındaki milliyetçi akımlar yeniden canlanmıştır. Ancak, buna karşın İspanyolculuk akımında, Franco'nun Ulusalkatolikliği ile mutlak özdeşleşmesinden dolayı İspanyol belleğinde belli bir gerileme yaşandi. Diktatörlüğe karşı olan ilerici sosyal kesimler, geçmişin bu vizyonuna muhaliftirler. Onlar Reconquista kavramına güçlü bir şekilde bağlıdırlar. Buna dayalı olarak İspanyollar yalnızca Katoliklik ve Ortaçağ Hıristiyan krallıklarından başlayan tarihi gelenek ile özdeşleştirilir. Bu, İspanya'nın ilerici sosyal kesimler ve solcu siyasi gruplar arasındaki tarihî hâfızanın ayrılmaz bir parçası olarak Endülüslülere yapılan çağrıyı açıklıyor. Bu şekilde, Endülüs'e nisbetle tarihî belleğin kutuplaşmasını sağlayan eğilim, muhafazakâr çevrelerde negatif ve dışlayıcı, ilerici çevrelerde ise olumlu ve kapsayıcı olacak şekilde pekiştirildi.

Diktatörlüğün sona ermesinden bu yana, akademik alanda İspanyolculuğun artan bir gerilemesinden bahsetmek mümkün olsa da, daha geniş kolektif tarihî bellek alanında, XIX. yüzyıldan beri ortaya çıkan aynı önyargılar, ezberler ve klişeler daha geniş bir çerçevede asli niteliğini korumaktadır. Böylece XXI. yüzyılın başında güçlü bir paradoksa tanık oluyoruz. Son gelişmeler, İspanya'nın Endülüs dönemine ilişkin son otuz yılda kaydedilen muazzam araştırma ve bilgi birikimine rağmen, XIX. ve XX. yüzyıllar boyunca gelişimini gördüğümüz önyargıların ve ezberlerin güçlü mevcudiyetine işaret etmektedir. Olagüe tarafından icat edilen inkârcılık gibi şimdiye kadar akademik tarihçiliğe yabancı olan bazı mitler, tarihi bir sahtekârlığın meşrulaştırılmasının alışılmadık ve utanç verici bir örneği olarak, profesyonel İspanyol Arapçılık sektörleri tarafindan da benimsendi. ${ }^{4}$

\section{İspanyol Hâfızasında Endülüs Hakkında Devam Eden Bölünme}

Yeni yüzyılın ilk yılları, Endülüs hakkındaki iki zıt tarihî hâfızanın tezahürleri altında verimli geçti. Bu duruma etki eden birkaç faktörden söz edilebilir. 11 Eylül saldırılarından bu yana "İslamcı terörizm" olgusunun artan uluslararası önemi, İslam'ın Batı medeniyetine temel bir tehdit olarak yorumlanması için yeni deliller sağladı. Bu, özellikle 11 Mart'taki Madrid saldırılarıyla ilgili olarak ortaya çıkan bazı yorumlarda daha belirgindi.

Son yıllarda, Moriskoların (Endülüslü Müslümanlar) sınır dış1 edilmesi (1609), Müslüman fethi (711) veya Las Navas de Tolosa (İkâb, 1212) savaşı kadar önemli olan tarihi olayların yıldönümlerinin birbirine tesadüf etmesi, Endülüs'ü anlamanın iki farklı yoluyla ilişskili güçlü zıtlıkları yeniden ifade etmeye hizmet etti. Bir yanda Endülüs'ün tarihî mirasını değerlendirmekle güç bela ilgilenen muhafazakâr kesimler ve diğer yanda ise ilerici eğilimler. Bu eğilimler Endülüs'ü İspanyol tarihî belleğiyle bütünleştirme ihtiyacına çok daha meyilliydi. İki görüş taraftarları arasındaki karşıtlığın hem siyasi arenada hem de medyada önemli tezahürleri oldu.

İspanya'nın Müslümanlar ve İslam ile ilişkisini siyasetin ve medyanın merkezine yerleştiren 11 Mart Madrid saldırıları, toplumda mazi ile ilgili tartışmaların içeriğini etkileyecek bir dizi tepkiye yol açtı. Endülüs'ün İspanyol tarihî belleğine eklenmesi sorunu da işte böylesi bir menfi olgunun geçerliliğine dayanmaktadır. Muhafazakâr kesimlerin tepkisi, her firsatta İslam'ın tarih boyunca İspanya için temsil ettiği kalıcı tehdit fikriyle bağlantılı olan Reconquista söyleminin canlandırılmasından yararlanmak şeklinde oldu.

\footnotetext{
${ }^{4}$ E. González Ferrín, Historia General de al-Andalus, Córdoba, 2006.
} 
Tarihi bu şekilde okumanın yetkili sözcüsü, Eylül 2004'te Georgetown Kuzey Amerika Üniversitesi'nde verdiği terörizm dersinde J. Ma Aznar idi. Eski cumhurbaşkanı, İspanya'nın El-Kâide ile mücadelesinin 2003 yılında başlayan Irak savaşıyla ilgili olmadığını, bilakis "Moriskolar" tarafından işgal edilen İspanya'nın İslam'ın bir parçası olmayı reddetmesiyle ortaya çıktığını iddia etti. ${ }^{5}$ İspanya'nın Müslümanlar tarafından fethini çağdaş bir terör örgütünün saldırılarıyla bir gören bu Aznarcı bakış, bu şekilde Endülüs'ü gayrimeşru sayan tarih anlayışını "güncelleyerek" sürdürmektedir.

En tutucu kesimlerin Reconquista'yı tarihyazımına dayalı söylemle özdeşleştirme anlayışlarının sürmesi, İspanyol ana muhafazakâr siyasi partiye ait siyasi belgelerle de doğrulanmaktadır. Mesela Aleix Vidal-Quadras'ın Haziran 2008'de düzenlenen 16. Popüler Parti Kongresi'nde yaptığı siyasi konuşması, ayrıcalıklı İspanyolculuğun geçmişteki karakteristik vizyonunu ifade eder fakat içerisinde Endülüs'ün varlığına yer vermez. O konuşmanın metni şöyledir: ${ }^{6}$

"İspanyol Milleti, tarihî ve kültürel bir gerçeklik olarak, kökenleri itibarılla ekseriya Ortaçă̆ Hıristiyan krallıklarına dayanmaktadır. Ancak her şeyden önce, hepsinde ortak olan Roma ve Vizigot İspanya'sının mirasina ve bu krallıkların beş yüz yıl boyunca tesis edilen Kastilya, Aragon ve Navarra kralliklarınin Ispanya Monarşisine entegrasyonu sayesinde oluşan siyasi birliğe dayanmaktadır.'

$\mathrm{Bu}$ metin, İspanya'daki muhafazakâr ideolojik yelpazenin tamamının ortak paydasını oluşturan Reconquista kavramına İspanyol sağının bağlılığını açıkça ortaya koymaktadır. En radikal kanatta yer alan Plataforma por Cataluña'nın lideri Josep Anglada, 2010 y1lında yayınlanan ve bir ulusal kurtuluş girişimi olarak Reconquista için özür dilediği bir kitapta, yabancı düşmanı ve İslamofobik düşüncelerini şöyle ifade etti: ${ }^{7}$

"Bir ulus olarak İspanya aynı zamanda, VIII. yüzyılda çoğunluğu HispanoRomalı olan Hristiyanlara önderlik eden Vizigotların ahlaki zaaflarından yararlanarak bizi işgal eden Müslüman boyunduruğundan kurtulmayı hedefleyen tarihi ve endemik savaşın sonucudur ve Reconquista'nın başarısından sonra bu savaş, İslami tahayyüle ait Endülüs'ün kurtarllması özlemini gizli bir tehdit olarak gördüğ̈̈ ölçüde sürdü ki, bazılarına göre bu özlem sadece bugünkü Andalucia Bölgesi ile Murcia ve Badajoz'u değil, tüm İspanya 'yı ve hatta Güney Fransa 'yı da kapsamaktadır."

Aynı zamanda, önde gelen dini yetkililer, Ulusalkatolikliğe ait tarihî hâfızayı XXI. yüzyıl toplumunda da yaymayı sürdürdüler. Tarihçi rahip José Orlandis, Menéndez Pelayo'nun yukarıda alıntılanan ünlü bildirisini sahiplenmede tereddüt etmiyor: "Bir büyü ve kehanet karışımı ama nihayetinde tarihi deneyimin verilerinden ilham alıyor.. bugün şaşırtıcı bir gerçeklikle yankılanıyor". Benzer şekilde, İspanyol Kilisesi'nin en yüksek temsilcisi Kardinal Antonio Cañizares'in 2008'de yaptığı ve "Hıristiyanlığın Katolik inancının -halk tarafindan kabul edilsin-edilmesin- İspanya'nın ruhunu oluşturduğunu" belirttiği konuşması, gerçekte Kraliyet Tarih Akademisi'nin bir üyesi sıfatıyla formüle edilmiştir. ${ }^{8}$

Önceki vakanın gösterdiği gibi, özel İspanyol hâfızasının profesyonel tarihyazımı alanındaki 1srarını ortaya koyan ana paradigma, daha çok Kraliyet Tarih Akademisi ile bağlantılı

\footnotetext{
${ }^{5}$ El Mundo, 22-9-2004.

${ }^{6} \mathrm{http}: / /$ www.partidopopular.us/actividades/16congreso/16congreso.htm\#ponencias. Erişim 23-11-2013.

${ }^{7}$ Anglada, J., Sin mordaza y sin velos, Barcelona, 2010, s. 385.

${ }^{8}$ A. Cañizares Llovera, El esplendor visigótico, s. 44.
} 
yazarlardan çıkmaktadır. Tarih konusundaki düşüncelerinde Jaime Balmes geleneğine başvuran ve Endülüs'ün sekiz asırlık geçerliliğini sadece "İspanyol ulusunun yaşamında bir fâsıla" durumuna indirgeyen Luis Suárez Fernández'in durumu da böyledir. ${ }^{9}$ Çok benzer bir içerikte, Arabist ve aynı zamanda akademisyen Serafín Fanjul'un da bir tarihyazım çalışması vardır: $A l$ Andalus frente a España -2001 (İspanya'ya karş1 Endülüs). Fanjul, İspanyol ile Endülüslü arasındaki muhalefet fikrinin coşkulu bir savunucusudur. Onun "Endülüs Efsanesi" iddiaları, bu tarihi döneme yönelik hoşgörü fikrini reddeder. Bu akademik çalışma, en muhafazakâr İspanyol tarihyazım söylemini yaymaya kararlı olan yayıncılar ve propagandacılar tarafindan geliştirilen görüşlere karşıt bir teze sahiptir. Önde gelen temsilcilerinden biri de César Vidal'dir. O España frente al Islam - 2004 (İslam'a karşı İspanya) adlı kitabında, İspanyol'un antitezi olarak İslam'ın konuşlandırılmasında ısrar eder, hatta 11 Mart Madrid saldırılarının ardından Antonio Elorza adında bir akademisyenin yaptığ 1 gibi, Muhammed'i terörist ${ }^{10}$ olarak karakterize ederek ona "insanlığa karşı işlenmiş suçlar" atfeder. ${ }^{11}$ Tarihe meraklı bir başka sağcı medya sözcüsü José Javier Esparza ise, Santiago y cierra: El nacimiento de una nación - 2013 (Bir Ulusun Doğuşu) eserinde, orijinal ve anlamlı başlıklarla Reconquista fikrinin efsanevi ve yüceltici yanlarının derlenmesine odaklanır.

Daha muhafazakâr çevreler arasındaki dışlayıcı retoriğin ısrarcı çekiciliği karşısında, akademik alanda farklı bir akımın gelişmekte olduğunu da bilmek gerekir. Bu akım, yarımadanın Ortaçağlardaki geçmişine ilişkin önyargılı fikirlerin oluşumunda kritik öneme sahip belirli kavramlara yönelik daha eleştirel bir görüşe sahiptir. Bu meyanda, Ortaçağcı José Luis Corral Lafuente'nin, geleneksel önyargıların ağır bir şekilde bastırdığı bir tarihî belleğin kötü şöhretli önyargılarını ve çarpıtmalarını düzeltmeyi amaçlayan yayınları mühimdir. ${ }^{12}$

İspanya'da son yıllarda, belirli tarihi olayların yıldönümlerine paralel olarak, Endülüslülerin İspanyol tarihî belleğine daha fazla entegrasyonunu amaçlayan çeşitli sosyal ve politik girişimler görülmüştür. Bazı iletişim araçlarının ve siyasi grupların onlara karşı takındığı tutumlar, Endülüs'ten İspanya'ya geçiş döneminden itibaren tarihî bellekte mevcut olan kutuplaşmanın ne denli geçerli olduğunu mükemmel bir şekilde ortaya koymaktadır. Büyük ölçüde bu girişimler lehine gruplara ilham kaynağı olan bu model, Medeni Kanunun İspanyol vatandaşlığı edinme konusunda tercihli hak tanıdığ 1 Sefarad Yahudilerinin torunları için çıkarılan kanun olmuştur ki bu girişim 1990'da Asturias Prensliği Barış Ödülü ile ödüllendirildi. Bununla birlikte, Sefarad Yahudilerinin tarihî hâfızasını Moriskolarınkilerle bir tutmaya yönelik tüm girişimler, muhafazakâr siyaset ve medya sektörlerinin topyekûn bir muhalefetiyle karşılaştı ve bu direnç bu tür müsbet girişimlerin neden tamamen başarısızlıkla sonuçlandığını da açıklıyor. Bu tutum, 2011'de yaptığı yeni Anayasasının girişinde, Endülüs mirasını kendi milli birliğini besleyen ve zenginleştiren bileşenlerden biri olarak tanıyan Fas'ta (el-Mağrib) hâkim olan yaklaşım ile çelişmektedir. ${ }^{13}$

Fas'ta 2011'deki başarılı girişime en yakın emsal, Şubat 2002'de tescil edilmişti. Bu girişim ise, 1502 'de Katolik hükümdarlar tarafından çıkarılarak uygulanan ve Endülüs Müslümanlarının din değiştirme veya sürgün arasında seçim yapmaya zorlanmasını öngören kararnameye karşı başlatıldı. Şefşâven (Chefchaouen) şehrinde düzenlenen Birinci Endülüs Dünya Kongresi çerçevesinde katılımcılar, Kral Juan Carlos'a Muhammed Bin el-Azzûz el-

${ }^{9}$ L. Suárez Fernández, "Los fundamentos medievales”, s. 125.

${ }^{10}$ C. Vidal, España frente al Islam, s. 59-60.

11 "Yihad en Madrid", "El País" - 18-3-2004.

12 J. L. Corral, "La manipulación...”, bid.

13 Fas Sultanlığı, Resmi Bülten, nu. 5952, 14 Receb 1432 /17 Haziran 2011, çevrimiçi: https://www.maroc.ma/ar 
Hâkim tarafindan yazılan bir mektubu göndermeye karar verdiler. ${ }^{14}$ Bu mektupta, Faslı Hispanistlerin dekanı, sınır dışı etme kararnamesinin iptalini ve Moriskoların torunlarının durumunu Sefaradlarınkilerle eşitleyecek telafi jestlerinin yapılmasını talep etti. ${ }^{15}$

$\mathrm{Bu}$ girişimin tamamen etkisiz kalması üzerine, bundan dört yıl sonra ve şimdi İspanya'dan yine Moriskoların İspanyol vatandaşlığı almak için tercihli hak elde etmelerini amaçlayan ikinci bir girişim başlatıldı. Bu girişim, 2006 yılının Eylül ayında Endülüs Parlamentosunda Izquierda Unida Los Verdes-Convocatoria por Andalucía (Birleşik Sol) kuruluşu tarafından gündem dış1 sunulan bir teklifti. Bu kuruluşun savunması, Córdoba Üniversitesi Medeni Hukuk profesörü Antonio Manuel Rodríguez Ramos tarafından yapıldı. Antonio, "Mağribi" veya "Endülüslü" terimlerini tanıtarak sunduğu önerisinde, Endülüslülere ikamet hakkı ile İspanyol vatandaşlığı verilmesini düzenleyen 22.1 maddesinin yenilenmesini talep etti. ${ }^{16}$

2009 yılı, 1609'da III. Felipe tarafından çıkarılan kanunla Moriskoların sınır dış1 edilmesinin 400. yılına tesadüf ettiği için, Endülüs'ün tarihî hâfızası açısından özel öneme sahip bir yıldı. 1492'de Gırnata'nın zaptı, resmi olarak, yarımadadaki Müslüman varlığının sonu anlamına geliyordu ki kovulanlar vaftiz edilmiş Müslümanlar yani Hıristiyanlardı.

Granada Sosyalist Partisi milletvekili José Antonio Pérez Tapias, hükümeti hem Moriskoların soyundan gelenleri memnuniyetle karşılayacak hem de Mağrip ve Sahra Altı Afrika halklarıyla "ekonomik, sosyal ve kültürel bağları güçlendirecek" tedbirleri almaya çağıran bir usul-dışı teklifi parlamentoya sundu. Bu, muhafazakâr oluşumlar PP ve CIU aleyhine oylarla onaylanan bir girişim oldu. ${ }^{17}$

$\mathrm{Bu}$ girişimin muhafazakâr basın tarafından benimsenmesi, Endülüs'e ilişkin öldürücü reddetme ve kılık değiştirmemiş alaycılık arasında gidip gelen özel bir tarihî hâfızanın varlığını net şekilde ortaya koymaktadır. Hâlbuki 1990 'da, Asturias Prensi'nin Sefarad Yahudilerinin torunlarına verdiği imtiyazla ilgili "uzlaşma" terimleriyle konuşan aynı gazete, hasarı tamir etme niyetini "gülünç" olarak nitelendirerek, söz konusu parlamentonun Moriskoların sınır dış1 edilmesinden kaynaklanan girişimine tamamen karşıydılar-ve herhangi bir uzlaşma fikrinden uzak olarak bu tür "saçmalıkları" - "hayali bir-kolektif hâfızayı kurtarma" arzusuyla ilişkilendiriyorlardı. Fakat şimdi, Müslümanların durumuyla Yahudilerinki arasında bir paralellik kuracak kadar ileri gidiyor ve her iki olayın da "modern ve demokratik bir toplumun anlaması ve saçma sorumluluklar yüklemeden üstlenmesi gereken tarihi bir görevin parçası olduğunu" belirtiyor. Varılan yer, diğer benzer olaylara karşı gösterilen tutumla daha çelişkili olamazdı. Nitekim söz konusu gazeteye göre, Moriskoların sınır dışı edilmesiyle ilgili ilerleyen süreç, gerçekte "uzmanların sağduyu ve tarafsızlık kıstaslarıyla çalışmasına izin vermek" manasina gelmekteydi. ${ }^{18}$

Muhafazakâr basın köşe yazarları, hepsi de çok benzer bir delile dayalı olarak, her zaman mutlak oybirliğiyle reddedilen bu öneri hakkında yorum yapmak için köşelerinde geniş yer ayırdılar. En sık tekrarlanan yorumlardan biri, "1936'ya kadar Yarımada'da kaydedilen en kanlı çatışma” olarak sınıflandırılan sözde Alpujarras Savaşı'nı hatırlatarak Moriskoları suçlu

\footnotetext{
${ }^{14}$ El País, 14-2-2002.

${ }^{15}$ Mektubun metni ve değerlendirmesi için bkz. Alejandro García-Sanjuán, "Rejecting al-Andalus, exalting the Reconquista: historical memory in contemporary Spain", çevrimiçi: tandfonline.com/doi/full/10.1080/17546559.2016.1268263 - 14.01.2021 (L.Ş.).

${ }^{16}$ Endülüs Parlamentosu (BOPA) Resmi Gazetesi - 519, 2 Ekim 2006.

${ }^{17}$ Resmi Kongre Gazetesi (BOCG). 12/11/2009 tarihli D-308 Say1lı Milletvekilleri Kongresi.

${ }^{18} A B C, 25-11-2009$.
} 
saymaktı. ${ }^{19}$ Benzer şekilde, bu başyazıya uygun olarak diğerleri de dönemin başbakanını, Mağribi "sis perdesi"ni "gerçekliği görmememiz için bir kum firtınası" ş̧eklinde kullanarak, zaten belirgin olan ekonomik krizin gerçekliğini maskelemekle suçladı. ${ }^{20}$

2010 yılında ilerici kesimler ve sol partiler, Endülüs'ün İspanyol tarihî belleğiyle bütünleştirilmesini sağlamak maksadıyla yeni bir girişim daha başlattılar. Girişimin muhtevasında, 1990 yılında Sefaradlara verilen haklar ile o girişime layık görülen Asturias Prensi Ödülü'nün Moriskolara da verilmesi öngörülüyordu. Ödül adaylık belgesi, Blas Infante Vakfı ve Casa de Sefarad (Córdoba) gibi kuruluşların yanısıra, aralarında Fransız-Lübnanlı yazar Amin Maalouf (2010 Asturias Prensi Edebiyat Ödülü) ile İspanyol kültürü üzerine çalışan isimler Juan Goytisolo ve José Saramago (1998 Nobel Edebiyat Ödülü) gibi isimlerin bulunduğu prestijli entelektüeller tarafından da imzalandı.

Siyasi alanda ise, Pérez Tapias aracılığıyla PSOE imza kampanyasına katıldı. Endülüs Parlamentosu, bünyesinde temsil edilen üç siyasi grubun (PSOE, PP ve IU) imzaladığ beyanname ile adaylık kampanyasına kurumsal destek sağladı. Bu son gerçek, Endülüs'ün tarihî hâfizasıyla ilgili olarak sağ ve sol siyasi partiler arasındaki gerçekleşen oybirliği benzeri az görülen örneklerden birini oluşturması nedeniyle, özel bir öneme sahiptir. ${ }^{21} \mathrm{Ne}$ var ki, diğer ikisinde olduğu gibi, Moriskoların sınır dışı edilmesine kurumsal meşruiyet sağlamak için yapılan bu üçüncü girişim de, aşırı muhafazakâr kesimler tarafından tamamen reddedildi.

2012 yılı, Endülüs'te Muvahhidler'in düşüşünü başlatan ve Endülüs topraklarının Guadalquivir'deki (Vâdilkebîr) Kastilya kralları tarafından zaptının başlamasını sağlayan Las Navas de Tolosa (İkâb) Savaşı'nın 800. yılına tesadüf etti. PSOE tarafından yönetilen Jaén Eyalet Konseyi ile hepsi PP'den olan La Carolina, Santa Elena ve Vílches belediye başkanları arasında, bu tarihi olayın anılmasına, buna bağlı olarak Reconquista fikrine ve Endülüs'ün tasfiyesi konusuna yaklaşım farklılığı dolayısıyla anlaşmazlık vardı.

Jaen'e bağlı La Carolina kasabasının belediye başkanı Francisco Gallarín, orduya ve kiliseye bir bağış yaparak olay yerinde yaptırdığı bir ayinle, Reconquista savaşının canlandırıldığı anma töreninde sergilediği vatansever ve Katolik tutumu nedeniyle, ulusal medya tarafindan "XXI. yüzyılın Don Pelayo'su" (718'de Reconquista hareketini başlatan kişi, L.Ş.) olarak tanımlandı. ${ }^{22}$

Zikredilen bu örnekte olduğu gibi, Ortaçağ ile bağlantılı düzenlenen birçok faaliyet, bu olayların geniş toplumsal köklerini ve güçlü siyasi izdüşüme sahip tarihî bellekten doğan göstergelerinin varlığını ispat etmektedir. En iyi bilinen ve tartışmalı olanlardan biri, Katolik hükümdarların 2 Ocak 1492'de Gırnâta'ya girişinin ve Endülüs'ün tarihi bir varlık olarak sona ermesinin anısına yapılandır. Her yıl bu tarihte şehir, askeri ve dini unsurların katılımıyla belediye kurumunun düzenlediği halka açık bir anma töreni olan Alma Günü'nü kutlamaktadır. Neredeyse demokrasinin başlangıcından bu yana, İspanya'nın kökeni olarak Reconquista mefhumuyla bağlantılı geçmişin vizyonuna bağlılığın alameti olarak düzenlenen bu kutlama, bir fetih ve şiddet eyleminin kamuoyunda anılmasını reddeden ilerici kesimler ile partinin coşkulu taraftarları olan en gelenekselci, muhafazakâr ve aşırı sağcılar arasında güçlü bir tartışmaya damgasını vurdu.

Bu kutlama ekibi 2013 yılında bir bölünme yaşadı. PSOE ve IU'nun belediye grupları eylemlere katılmadığı için, resmi delegasyon yalnızca hükümet ekibi, PP ve UPyD'li bir meclis

\footnotetext{
${ }^{19}$ Manuel Martín Ferrand, “¿Que vienen los turcos!” (Türkler geliyor!), ABC, 26-11-2009.

${ }^{20}$ J. Félix Machuca, "Morisquetas moriscas" (Mağribli Moriskolar), ABC, 26-11-2009.

${ }^{21}$ BOPA 404, 7 Temmuz 2010.

${ }^{22}$ El País (Andalucía), 5-11-2011.
} 
üyesinden oluştu. Ancak, yeni unsurlar da vardı. Junta de Andalucía'nın Tarihsel Hafiza Genel Müdürü ile Izquierda Unida'dan Luis Naranjo da kutlamaya karşı olduğunu açıkladı ve bunun yerine, alternatif eyleme olan desteğini gösterdi: "Alma'ya Hayır, Mariana'ya Evet". 26 Mayıs'ta 2 Ocak kutlamalarını bastırmak ve onun yerine Mariana Pineda'nın idamını anmak amacıyla Granada Abierta kutlamasını önerdi. ${ }^{23}$ Junta de Andalucía'nın bu teklifi, muhafazakâr basında "palyaçoluk" ve "Endülüs solunun saçma efsaneleri" şeklinde yorumlandı. ${ }^{24}$

Solun bu girişimine bir tepki olarak, PP tarafından yönetilen Diputación de Granada, Nisan ayında Junta de Andalucía tarafından festivalin bir Kültürel İlgi Alanı olarak ilan edilmesini önerdi. Bu, ulusal basında eleştirel yorumlara konu oldu.

El País gazetesinin başyazarı, "Gırnâta'nın İspanya tarihinin bir parçası olarak alınması varsayımının, Unesco şemsiyesi altında Katolik silahlanmadan önce Müslümanların yenilgisini kutlama iddiasıyla hiçbir ilgisi olmadığı" varsayımıyla teklife karşı çıktı. "Böyle bir ifadeden farklılıkları derinleştirmek dışında başka hangi mesaj çıkabilir?"25 Son olarak, PP'nin teklifi Endülüs Parlamentosunda sol oluşumların (PSOE ve IU) oylarıyla reddedildi. ${ }^{26}$

Tarafların ele alınan bu tutum repertuvarı, son on yılda İspanya'da Endülüs tarihî hâfızası meselesi üzerine yapılan tartışmaların gelecekte de devam edeceğini gösteriyor. Nitekim medyada defalarca belgelenen muhtelif yansımalar ve olaylar, bu sorunun değişmeden sürdüğü gerçekliğini vurgulamaktadır. 2004 yılında Aragon Hükümeti, bağımsızlık anıtını süsleyen kesilmiş Morisko kafalarının ortadan kaldırılmasını görüştü. ${ }^{27}$ Yerel düzeyde, Malaga'nın Canillas de Aceituno sâkinleri, 2008'de, Granada'nın son Müslüman sultanı Ebû Abdullah'ın (Boabdil) boynuna bağlanan zinciri, "geçmiş zamanlara ait bir çatışma unsurunu temsil ettiği için belediye armasından çıkarmaya karar verdi". ${ }^{28} \mathrm{Bu}$ olumlu gelişmelere, Algeciras (elMansûr), Murcia (II. Abdurrahman), Badajoz (İbn Mervân el-Cillîkî), Niebla ve Huelva (İbn Mahfûz) gibi farkl「 yerlerde Endülüs'ün tarihî şahsiyetlerine ait anıtların çoğalması da eklenmelidir.

Analiz edilen gelişmeler ve gerçeklikler, Endülüs ya da Endülüslülere yönelik tarihî anma ya da bayramların İspanya'daki sürekliliğini belgeleyen unsurlar olarak anlaşılmalıdır. Bu anmaların kökeni XIX. yüzyıl tarihçiliğinde olup, XIX-XX. yüzyılların İspanya'sında geniş bir gelişme göstermiştir. XXI. yüzyılda arzu edilir ki, İspanyol toplumunda hala güçlü bir şekilde varlığını sürdüren; hakikatleri çarpıtıcı, örtücü, tahrif edici ve anakronik tüm tarihî yaklaşımlar kesin olarak ortadan kaldırılsın. Bu hedef ise, ancak profesyonel tarihçilerin bu görevi üstlenmeleri sayesinde mümkün olacaktır.

${ }^{23}$ El País, 1-1-2013.

${ }^{24}$ Hermann Tertsch, "Boabdil y el maquis", $A B C, 4-1-2013$.

${ }^{25}$ El País, 4-1-2013.

${ }^{26} A B C, 11-4-2013$.

${ }^{27} A B C, 19-10-2004$.

28 “ $A B C, 14-5-2008$. 


\section{Bibliyografya}

Anglada, J. Sin mordaza y sin velos. Barcelona. 2010.

Cañizares Llovera, A. El esplendor visigótico, momento clave en la edificación de España y para su futuro: discurso leído el día 24 de febrero de 2008 en el acto de su recepción pública. Madrid. 2008.

Corral, J. L. «La manipulación política de la Historia de España: el caso de al-Andalus», La divulgación de la historia y otros estudios sobre Extremadura. X Jornadas de Historia en Llerena, Llerena, 25-38. 2010.

García Sanjuán, A. «Al-Andalus en la historiografía del nacionalismo españolista (siglos XIX-XXI). Entre la España musulmana y la Reconquista», D. Melo Carrasco y F. Vidal Castro (ed.): A 1300 años de la conquista de al-Andalus (711-2011): historia, cultura y legado del Islam en la península Ibérica, Coquimbo (Chile), 2012, páginas 65-104. 2012.

La conquista islámica de la península Ibérica y la tergiversación del pasado: del catastrofismo al negacionismo. Madrid. 2013.

González Ferrín, E. Historia general de al-Andalus. Córdoba. 2006.

Marco Sola, L. «El catolicismo identitario en la construcción de la idea de nación española. Menéndez Pelayo y su Historia de los Heterodoxos Españoles», Ilu, 14, 101-116. 2009.

Orlandis, J. «Sobre los orígenes de la nación española», Memories de la Reial Academia Mallorquina d'Estudis Genealogics, Heraldics $i$ Historics, 17, 7-17. 2007.

Sánchez-Albornoz, C. El Islam de España y el Occidente. Madrid. 1974.

Suárez Fernández, L. «Los fundamentos medievales de la nación española», E. Benito Ruano (ed.): Tópicos y realidades de la Edad Media (III), Madrid, 121-134. 2004.

Vidal Manzares, C. España frente al Islam. Madrid. 2004. 